\title{
Sistem Diagnosa Penyakit Dalam dengan Menggunakan Jaringan Saraf Tiruan Metode Backpropagation dan Learning Vector Quantization
}

\author{
Zeth Arthur Leleury ${ }^{1}$, Yopi Andry Lesnussa ${ }^{2}$, Julianty Madiuw ${ }^{3}$ \\ 1,2) Jurusan Matematika, Fakultas MIPA, Universitas Pattimura \\ Jln. Ir. M. Putuhena, Kampus Unpatti, Poka-Ambon \\ Email: zetharthur82@gmail.com,yopi_a_lesnussa@yahoo.com,_madiuwjulianti@gmail.com
}

\begin{abstract}
ABSTRAK
Jaringan saraf tiruan telah banyak digunakan untuk membantu menyelesaikan berbagai macam permasalahan dalam rangka pengambilan keputusan berdasarkan pelatihan yang diberikan. Jaringan saraf tiruan dapat diaplikasikan pada berbagai bidang dalam kehidupan manusia, salah satunya bidang kesehatan. Dalam penelitian ini, jaringan saraf tiruan digunakan untuk mendiagnosa Penyakit Dalam dengan menggunakan metode Backpropagation dan Learning Vector Quantization yang selanjutnya akan dibandingkan hasil diagnosa dari kedua metode tersebut. Data penelitian sebanyak 266 data, dengan 190 data sebagai data pelatihan dan 76 data sebagai data pengujian yang diambil dari data pasien RSUD Dr. M. Haulussy, Ambon. Dengan menggunakan metode Backpropagation tingkat keakuratan diagnosanya sebesar $61.84 \%$ sedangkan dengan menggunakan metode LVQ tingkat keakuratan diagnosanya sebesar $93.42 \%$. Dari hasil penelitian ini metode LVQ dianggap lebih baik dalam mendiagnosa Penyakit Dalam.
\end{abstract}

Kata kunci: Jaringan Saraf Tiruan, Backpropagation, Learning Vector Quantization, Penyakit Dalam

\section{ABSTRACT}

Artificial neural networks have been widely used to help sove various problem in the context of decision making based on the training provided. The artificial neural networks will be applied on many fields of human life. One of them is the fields of health. In this research, the artificial neural networks is used to diagnose Internal Diseases using the Backpropagation and Learning Vector Quantization methods, which later will be compared one to another. The number of data used in this research is 266 , 190 of them is used as training data and the remaining as testing data. The data are collected from RSUD Dr. M. Haulussy, Ambon. Using the Backpropagation methods, the diagnose accuracy rate is $61.84 \%$ and using the Learning Vector Quantization method, the diagnose accuracy rate is $93.42 \%$. Based on the data above, $L V Q$ is considered as a much better method for diagnosing Internal Diseases.

Keywords: Artificial Neural Networks, Backpropagation, Learning Vector Quantization, Internal Diseases.

\section{Pendahuluan}

Cara Komputer memiliki peranan yang sangat penting untuk membantu pekerjaan manusia dalam segala aspek bidang. Pemakai mulanya menggunakan komputer sebagai mesin ketik yang dapat bekerja lebih cepat, tepat, maupun otomatis. Seiring dengan perkembangan saat ini, para ahli coba menggantikan komputer menjadi suatu alat bantu yang dapat meniru cara kerja otak, sehingga diharapkan suatu saat akan tercipta komputer yang menimbang dan mengambil keputusan sendiri. Hal inilah yang mendorong lahirnya teknologi kecerdasan buatan (artificial intelligence). Salah satu teknik komputasi yang dikelompokkan dalam kecerdasan buatan adalah jaringan saraf tiruan (artificial neural network). Jaringan saraf tiruan merupakan salah satu sistem pemrosesan yang dirancang dan dilatih untuk memiliki kemampuan seperti yang dimiliki oleh manusia dalam menyelesaikan persoalan yang rumit dengan melakukan proses belajar melalui perubahan bobot. Jaringan saraf mensimulasi struktur proses-proses otak (fungsi saraf biologis) dan kemudian membawanya kepada perangkat lunak kelas baru yang dapat mengenali pola-pola yang kompleks. Jaringan saraf tiruan (JST) merupakan sistem pemrosesan informasi yang mempunyai penampilan karakteristik menyerupai jaringan saraf biologi (Fauset, 1994). 
JST adalah salah satu alternatif pemecahan masalah dan banyak diminati oleh para peneliti pada saat ini. Penelitian tentang aplikasi penggunaan JST melalui pengenalan pola terhadap terjadinya sesuatu telah banyak dikaji dalam berbagai ilmu pengetahuan, diantaranya di bidang kedokteran untuk diagnosa penyakit. Iatrical scholar menggunakan jaringan Self-Organizing Map (SOM) dan teori himpunan untuk menemukan kecenderungan kondisi pasien penderita penyakit kardiovaskular secara individual (Chou et al, 2007). Penelitian (Gil et al, 2009) menggunakan jaringan SOM untuk mendiagnosa disfungsi penyakit urologi. Selain jaringan SOM, ada juga jaringan saraf tiruan Backpropagation dan Learning Vector Quantization (LVQ) yang dapat diaplikasikan untuk proses diagnosa.

Backpropagation merupakan algoritma pembelajaran yang terawasi dan biasanya digunakan oleh perceptron dengan banyak lapisan untuk mengubah bobot-bobot yang berhubungan dengan neuronneuron yang ada pada lapisan tersembunyinya. Algoritma backpropagation menggunakan error output untuk mengubah nilai bobot-bobotnya dalam arah mundur (backward). Untuk mendapatkan error ini, tahap perambatan maju (forward propagation) harus dikerjakan terlebih dahulu (Tanjung, 2014). Sedangkan jaringan LVQ merupakan jaringan yang berbasis kompetitif dimana dari nilai keluaran yang diberikan neuron dalam layer keluaran hanya neuron pemenang saja yang diperhatikan. Neuron pemenang tersebut yang akan mengalami pembaruan bobot. LVQ memiliki kelebihan seperti nilai error lebih kecil dibandingkan metode lain serta model yang dihasilkan dapat diperbaharui secara bertahap. Jaringan LVQ berhasil digunakan dalam klasifikasi dari dataset penyakit tiroid untuk memperoleh diagnosa (Temurtas, 2007) dan juga dalam mendiagnosa penyakit saluran pernapasan (Leleury, 2016). Jaringan saraf tiruan dalam mendiagnosa jenis penyakit menyimpan sejumlah data meliputi informasi pada gejala, diagnosis, dan informasi lainnya. Pelatihan jaringan saraf dapat dipresentasikan dengan input yang terdiri dari serangkaian gejala yang diidap oleh penderita. Setelah itu jaringan saraf akan melatih input tersebut sehingga ditemukan suatu akibat dari gejala tersebut yaitu jenis penyakitnya.

Penyakit Dalam merupakan penyakit yang sangat beragam jenis dan gejalanya sehingga seorang dokter perlu mengkaji lebih mendalam gejala yang dialami pasien untuk selanjutnya diputuskan hasil diagnosa penyakit yang diderita pasien. Untuk itu perlu dipelajari dan dicoba membuat aplikasi jaringan saraf tiruan untuk mendiagnosa penyakit seperti gangguan pada jantung, hati, lambung dan lain-lain. Adapun tujuan penulisan ini adalah membuat sistem pengambilan keputusan dengan menerapkan jaringan saraf tiruan metode backpropagation dan LVQ untuk mendiagnosa jenis Penyakit Dalam berdasarkan gejala-gejala yang dirasakan oleh pasien secara cepat dan tepat sehingga dapat menentukan jenis pengobatan secepatnya.

\section{Metode Penelitian}

\subsection{Rancangan Penelitian}

Langkah-langkah yang merupakan rancangan penelitian ini terdiri dari 4 tahapan yaitu:

a. Pengumpulan data

Data yang dikumpulkan adalah hasil rekam medis pasien penderita Penyakit Dalam (Dispepsia Fungsional, Diabetes Melitus, Chronic Kidney Disease (CKD) atau Gagal Ginjal Kronis, Hepatitis, Malaria, Congestive Heart Failure (CHF) atau Gagal Jantung Kongestif, Tuberkulosis Paru (TB Paru), Gastroenteritis Akut (GEA) atau Diare Akut, Penyakit Paru Obstruktif Kronik (PPOK) dan Infeksi Saluran Kemih (ISK)) yakni data gejala-gejala yang dialami oleh setiap pasien dan jenis penyakit yang diderita berdasarkan diagnosa dokter. Data yang digunakan berupa data sekunder yang diperoleh dari 266 data rekam medis pasien penderita Penyakit Dalam di Rumah Sakit Dr. M. Haulussy Ambon. Data tersebut selanjutnya digunakan untuk melakukan pelatihan program dan sebagai data latih serta data uji untuk sistem. Data-data yang telah ada kemudian diolah berdasarkan kebutuhan agar dapat dijadikan data input serta akan dijadikan data latih dan data target sistem.

b. Merancang dan membuat sistem diagnosa Penyakit Dalam menggunakan software Matlab.

Setelah data-data terkait gejala-gejala setiap Penyakit Dalam diperoleh, langkah selanjutnya adalah merancang sistem diagnosa untuk mengenali gejala-gejala Penyakit Dalam yang ada.

c. Melakukan pengujian sistem

Pada tahap ini dilakukan pengujian terhadap sistem yang telah dirancang. Pengujian sistem dilakukan dengan menghitung tingkat akurasi sistem dalam mendiagnosa jenis penyakit pada data testing. 
d. Penarikan kesimpulan

Langkah ini merupakan langkah terkahir dari penelitian. Penarikan kesimpulan didasarkan pada hasil analisis dari penelitian yakni tingkat akurasi sistem yang dihasilkan pada proses mendiagnosa jenis penyakit saluran pernapasan.

\subsection{Arsitektur Jaringan Backpropagation dan LVQ}

Model jaringan backpropagation merupakan suatu teknik pembelajaran atau pelatihan supervised learning yang sangat baik dalam menangani masalah pengenalan pola-pola kompleks. Didalam jaringan backpropagation, setiap unit yang berada di lapisan input berhubungan dengan setiap unit yang ada di lapisan tersembunyi. Setiap unit yang ada di lapisan tersembunyi terhubung dengan setiap unit yang ada di lapisan output.

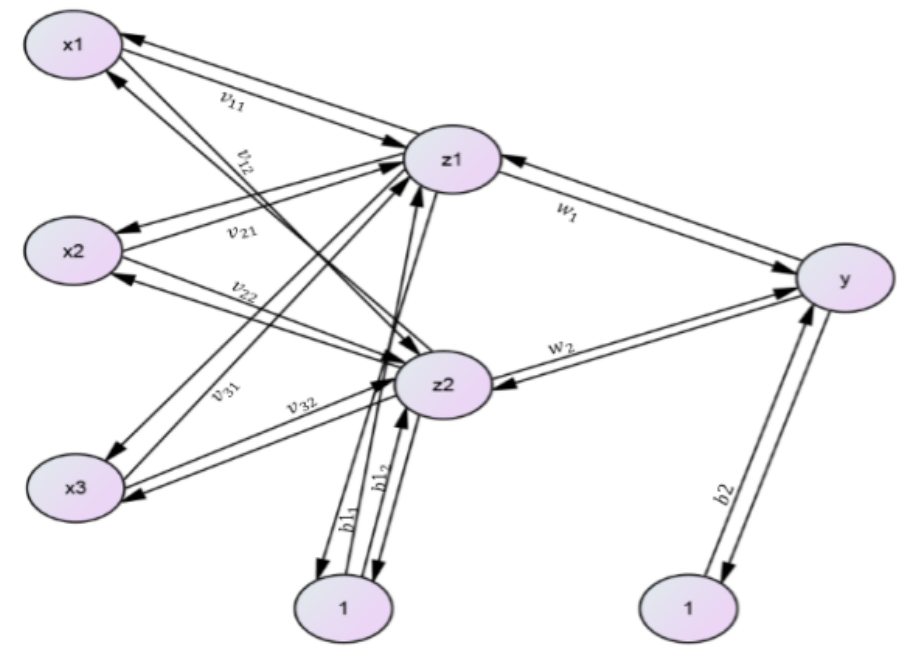

Gambar 1. Arsitektur jaringn saraf tiruan backpropagation

Arsitektur jaringan backpropagation terdiri dari tiga neuron pada lapisan input, yaitu $x_{1}, x_{2}, x_{3}$, 1 lapisan tersembunyi dengan 2 neuron, yaitu $z_{1}, z_{2}$, serta 1 unit pada lapisan output, yaitu $y_{1}$. Bobot yang menghubungkan $x_{1}, x_{2}, x_{3}$ dengan neuron pertama pada lapisan tersembunyi, adalah $v_{1}, v_{2}, v_{3}$. Untuk $b 1_{1}, b 1_{2}$ adalah bobot bias yang menuju ke neuronpertama dan kedua pada lapisan tersembunyi. Bobot yang menghubungkan $z_{1}, z_{2}$ dengan neuronpada lapisan output, adalah $w_{1}, w_{2}$. Bobot bias $b 2$ menghubungkan lapisan tersembunyi dengan lapisan output.

LVQ merupakan suatu metode klasifikasi dimana jumlah kelompok yang diharapkan sudah ditentukan. Berbeda dengan jaringan SOM, LVQ merupakan salah satu metode JST untuk melakukan pembelajaran terhadap layer yang terawasi (supervised).

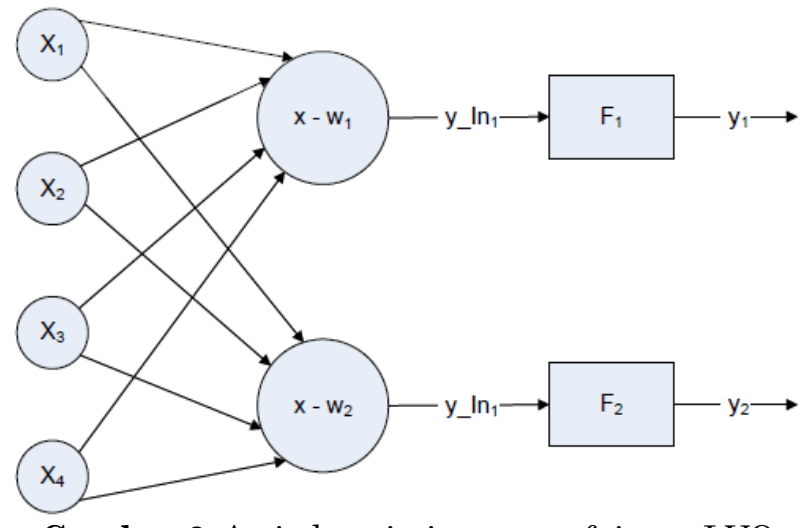

Gambar 2. Arsitektur jaringan saraf tiruan LVQ

Arsitektur di atas menunjukkan jaringan LVQ dengan unit pada lapisan input, dan 2 unit (neuron) pada lapisan output. Pemrosesan yang terjadi pada setiap neuron adalah mencari jarak antara suatu vektor input ke bobot yang bersangkutan $\left(w_{1}\right.$ dan $\left.w_{2}\right) . w_{1}$ adalah vektor bobot yang menghubungkan setiap neuron pada lapisan input ke neuron pertama pada lapisan output, sedangkan $w_{2}$ adalah vektor bobot yang menghubungkan setiap neuron pada lapisan 
input ke neuron yang kedua pada lapisan output. Fungsi aktivasi $F_{1}$ akan memetakan $y_{-} i n_{1}$ ke $y_{1}=1$ apabila $\left|x-w_{1}\right|<\left|x-w_{2}\right|$ dan $y_{1}=0$ jika sebaliknya. Demikian pula dengan yang terjadi pada fungsi aktivasi $\mathrm{F}_{2}$, akan memetakan $y_{-}$in $_{1}$ ke $y_{1}=1$ apabila $\left|x-w_{2}\right|<\left|x-w_{1}\right|$, dan $y_{1}=0$ jika sebaliknya (Hagan et al, 1996).

\subsection{Teknik Analisa Data}

Teknik analisis data dalam penelitian ini didasarkan pada algoritma proses pembelajaran pada metode Backpropagation dan LVQ yang dapat disajikan pada dua gambar berikut.

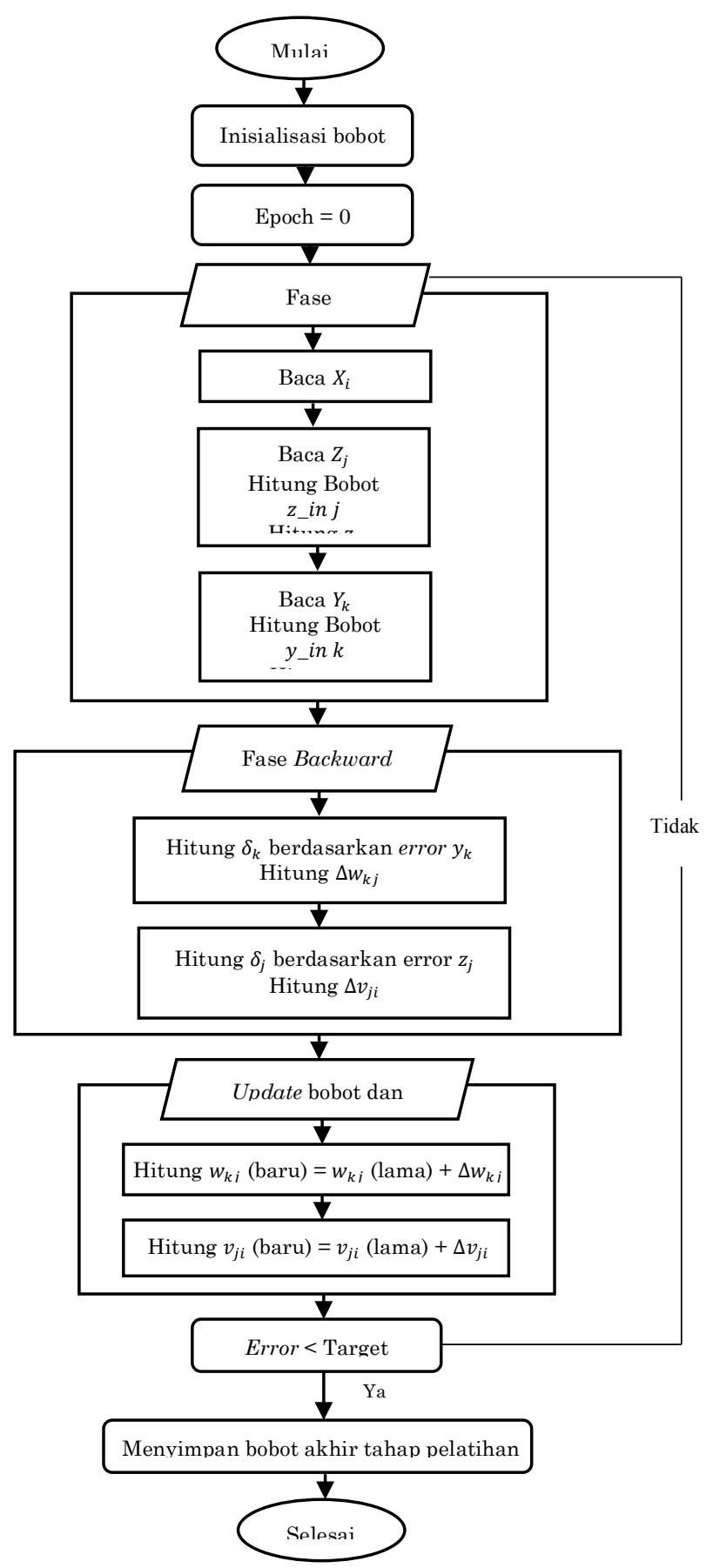

Gambar 3a. Diagram alir proses training pada jaringan backpropagation

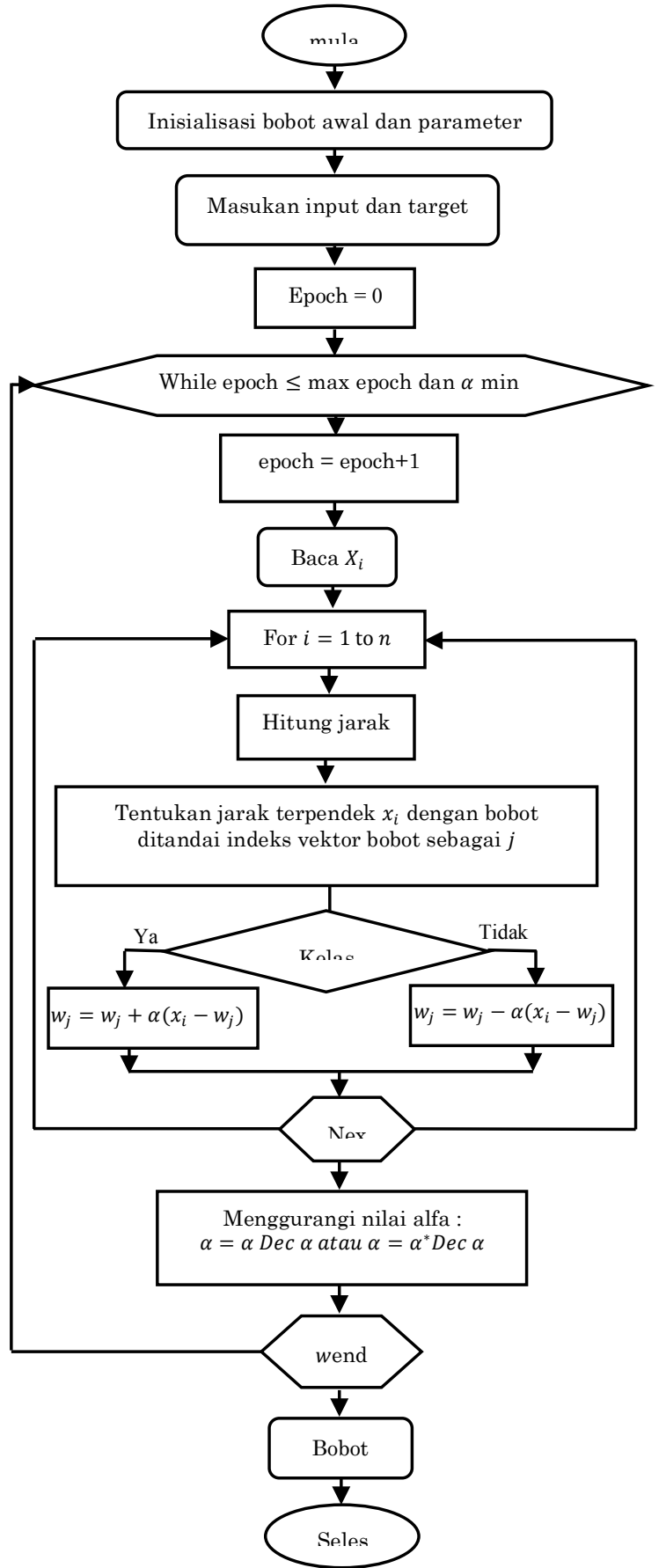

Gambar 3b. Diagram alir proses training pada jaringan $L V Q$ 


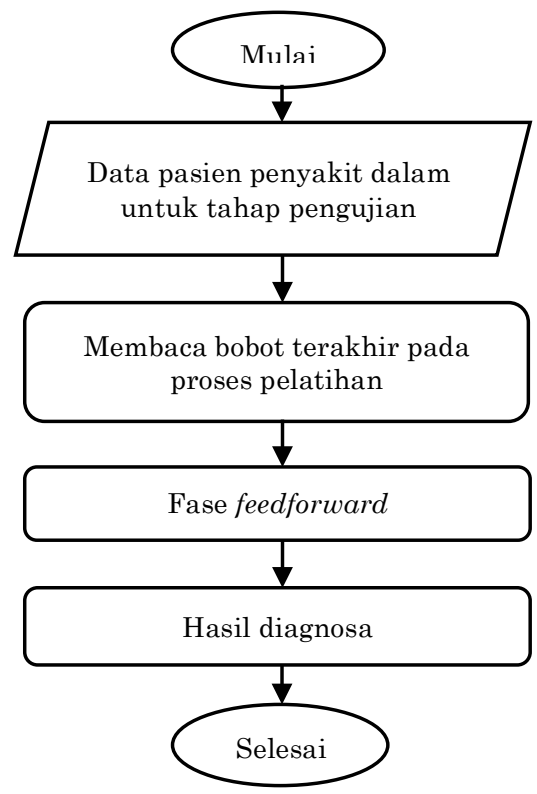

Gambar 4a. Diagram alir proses testing pada jaringan backpropagation

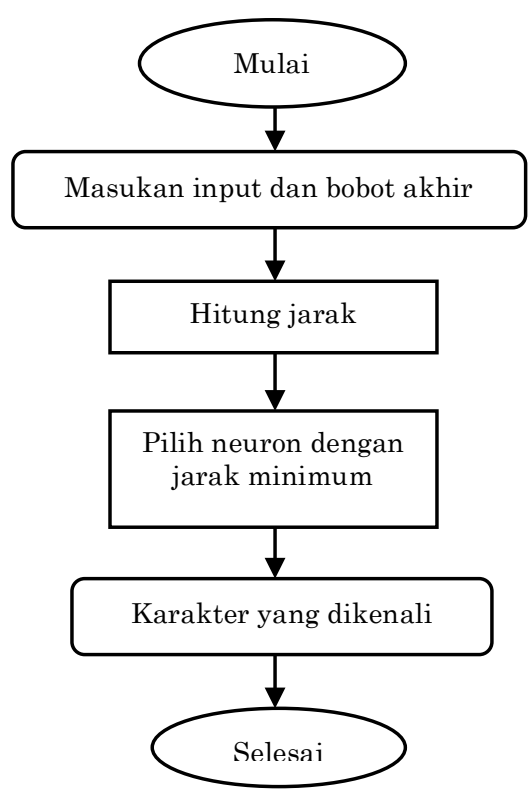

Gambar 4b. Diagram alir proses testing pada jaringan $L V Q$

Setelah dilakukan pelatihan maka akan diperoleh bobot-bobot akhir. Bobot ini selanjutnya akan digunakan untuk melakukan testing atau pengujian. Algoritma proses pengujian disajikan dalam Gambar 4 di atas.

\subsection{Penetapan Variabel Input}

Berdasarkan gejala klinisnya, Penyakit Dalam yaitu Dispepsia Fungsional, Diabetes Melitus, Chronic Kidney Disease (CKD) atau Gagal Ginjal Kronis, Hepatitis, Malaria, Congestive Heart Failure (CHF) atau Gagal Jantung Kongestif, Tuberkulosis Paru (TB Paru), Gastroenteritis Akut (GEA) atau Diare Akut, Penyakit Paru Obstruktif Kronik (PPOK) dan Infeksi Saluran Kemih (ISK) memiliki 40 gejala yang selanjutnya menjadi variabel input pada Jaringan Saraf Tiruan. Gejala-gejala tersebut adalah batuk, sesak nafas, nyeri dada, nyeri perut, nyeri kepala, nyeri ulu hati, nyeri sendi dan tulang, nyeri selangkangan, nyeri otot, malaise, anoreksia, berat badan menurun, perut kembung, perut tak enak, perut penuh, mual dan muntah, demam, dada terasa panas, menggigil, berkeringat dingin, susah tidur, nyeri perut bagian bawah, pusing, lemas, keram, BAB, ukus DM, gatal, pandangan kabur, tachypnoea, tachydarcia, penurunan kesadaran, bicara tak beraturan, tampak kuning, BAK, urine, BAK nyeri, limfadenopati, bengkak, dan edema tungkai.

Gejala-gejala penyakit saluran pernapasan tersebut ditentukan, selanjutnya adalah menentukan nilai dari masing-masing gejala. Nilai terhadap variabel ditentukan antara 0 sampai dengan 1, disesuaikan dengan kasus dari masing-masing gejala. Pada penelitian ini, ditetapkan jika semakin tinggi nilai dari variabel tersebut maka penyakit yang diderita semakin parah, dan sebaliknya semakin rendah nilai suatu variabel maka penyakit yang diderita semakin ringan. Adapun variabel dan nilai dari masing-masing gejala penyakit disajikan pada Tabel 1.

\subsection{Penetapan Variabel Output}

Selanjutnya output yang akan diperoleh adalah jenis Penyakit Dalam dengan rancangan penetapan keluaran (output) sebagai berikut :

- Diberi nilai "1" untuk pasien yang didiagnosa penyakit Dispepsia.

- Diberi nilai "2" untuk pasien yang didiagnosa penyakit DM

- Diberi nilai "3" untuk pasien yang didiagnosa penyakit CKD. 
- Diberi nilai "4" untuk pasien yang didiagnosa penyakit Hepatitis.

- Diberi nilai " 5 " untuk pasien yang didiagnosa penyakit Malaria.

- Diberi nilai "6" untuk pasien yang didiagnosa penyakit CHF.

- Diberi nilai "7" untuk pasien yang didiagnosa penyakit TB Paru.

- Diberi nilai "8” untuk pasien yang didiagnosa penyakit GEA.

- Diberi nilai "9" untuk pasien yang didiagnosa penyakit PPOK.

- Diberi nilai "10" untuk pasien yang didiagnosa penyakit ISK.

Tabel 1. Gejala-gejala penyakit dan nilainya

\begin{tabular}{|c|c|c|}
\hline Gejala-gejala & Variabel & Nilai \\
\hline \multirow{5}{*}{$\begin{array}{l}\text { Batuk } \\
\left(X_{1}\right)\end{array}$} & Tidak & 0 \\
\hline & Kering & 0.25 \\
\hline & Berdahak & 0.5 \\
\hline & Berdahak berubah warna & 0,75 \\
\hline & Berdahak berdarah & 1 \\
\hline \multirow{3}{*}{$\begin{array}{l}\text { Sesak nafas } \\
\qquad\left(X_{2}\right)\end{array}$} & Tidak & 0 \\
\hline & Jarang terjadi & 0.5 \\
\hline & Wheezing & 1 \\
\hline \multirow{3}{*}{$\begin{array}{c}\text { Nyeri dada } \\
\qquad\left(X_{3}\right)\end{array}$} & Tidak & 0 \\
\hline & Jarang terjadi & 0.5 \\
\hline & Sering Terjadi & 1 \\
\hline \multirow{3}{*}{$\begin{array}{l}\text { Nyeri perut } \\
\left(X_{4}\right)\end{array}$} & Tidak & 0 \\
\hline & Jarang terjadi & 0.5 \\
\hline & Sering terjadi & 1 \\
\hline \multirow{3}{*}{$\begin{array}{c}\text { Nyeri kepala } \\
\left(X_{5}\right)\end{array}$} & Tidak & 0 \\
\hline & Jarang terjadi & 0.5 \\
\hline & Sering terjadi & 1 \\
\hline \multirow{3}{*}{$\begin{array}{l}\text { Nyeri ulu hati } \\
\qquad\left(X_{6}\right)\end{array}$} & Tidak & 0 \\
\hline & Jarang terjadi & 0.5 \\
\hline & Sering terjadi & 1 \\
\hline \multirow{2}{*}{$\begin{array}{c}\text { Nyeri sendi } \\
\text { dan tulang } \\
\left(X_{7}\right)\end{array}$} & Tidak & 0 \\
\hline & $\mathrm{Ya}$ & 1 \\
\hline \multirow{2}{*}{$\begin{array}{c}\text { Nyeri } \\
\text { selangkangan } \\
\left(X_{8}\right)\end{array}$} & Tidak & 0 \\
\hline & $\mathrm{Ya}$ & 1 \\
\hline \multirow{2}{*}{$\begin{array}{l}\text { Nyeri otot } \\
\left(X_{9}\right)\end{array}$} & Tidak & 0 \\
\hline & $\mathrm{Ya}$ & 1 \\
\hline \multirow{2}{*}{$\begin{array}{l}\text { Malaise } \\
\quad\left(X_{10}\right)\end{array}$} & Tidak & 0 \\
\hline & $\mathrm{Ya}$ & 1 \\
\hline \multirow{2}{*}{$\begin{array}{l}\text { Anoreksia } \\
\quad\left(X_{11}\right)\end{array}$} & Tidak & 0 \\
\hline & $\mathrm{Ya}$ & 1 \\
\hline \multirow{2}{*}{$\begin{array}{c}\text { Berat badan } \\
\text { menurun } \\
\left(X_{12}\right)\end{array}$} & Tidak & 0 \\
\hline & $\mathrm{Ya}$ & 1 \\
\hline \multirow{2}{*}{$\begin{array}{c}\text { Perut } \\
\text { kembung } \\
\left(X_{13}\right)\end{array}$} & Tidak & 0 \\
\hline & $\mathrm{Ya}$ & 1 \\
\hline \multirow{2}{*}{$\begin{array}{l}\text { Perut tak } \\
\text { enak }\left(X_{14}\right)\end{array}$} & Tidak & 0 \\
\hline & Tegang & 0,5 \\
\hline
\end{tabular}

\begin{tabular}{|c|c|c|}
\hline Gejala-gejala & Variabel & Nilai \\
\hline \multirow{2}{*}{$\begin{array}{l}\text { Perut penuh } \\
\qquad\left(X_{15}\right)\end{array}$} & Tidak & 0 \\
\hline & Ya & 1 \\
\hline \multirow{5}{*}{$\begin{array}{l}\text { Mual dan } \\
\text { muntah } \\
\left(X_{16}\right)\end{array}$} & Tidak & 0 \\
\hline & Mual & 0.25 \\
\hline & Muntah & 0.5 \\
\hline & Mual \& muntah & 0.75 \\
\hline & Muntah darah & 1 \\
\hline \multirow{4}{*}{$\begin{array}{l}\text { Demam } \\
\left(X_{17}\right)\end{array}$} & Tidak & 0 \\
\hline & Jarang terjadi & 0.5 \\
\hline & Sering terjadi & 0,75 \\
\hline & Selalu terjadi & 1 \\
\hline \multirow{2}{*}{$\begin{array}{c}\text { Dada terasa } \\
\text { panas } \\
\left(X_{18}\right) \\
\end{array}$} & Tidak & 0 \\
\hline & $\mathrm{Ya}$ & 1 \\
\hline \multirow{2}{*}{$\begin{array}{l}\text { Menggigil } \\
\quad\left(X_{19}\right)\end{array}$} & Tidak & 0 \\
\hline & Ya & 1 \\
\hline \multirow{3}{*}{$\begin{array}{c}\text { Berkeringat } \\
\text { dingin } \\
\left(X_{20}\right)\end{array}$} & Tidak & 0 \\
\hline & Sering & 0.5 \\
\hline & Sering (malam hari) & 1 \\
\hline \multirow{2}{*}{$\begin{array}{l}\text { Susah tidur } \\
\qquad\left(X_{21}\right)\end{array}$} & Tidak & 0 \\
\hline & $\mathrm{Ya}$ & 1 \\
\hline \multirow{2}{*}{$\begin{array}{c}\text { Nyeri perut } \\
\text { bagian bawah } \\
\left(X_{22}\right)\end{array}$} & Tidak & 0 \\
\hline & $\mathrm{Ya}$ & 1 \\
\hline \multirow{2}{*}{$\begin{array}{c}\text { Pusing } \\
\left(X_{23}\right)\end{array}$} & Tidak & 0 \\
\hline & $\mathrm{Ya}$ & 1 \\
\hline \multirow{2}{*}{$\begin{array}{c}\text { Lemas } \\
\left(X_{24}\right)\end{array}$} & Tidak & 0 \\
\hline & $\mathrm{Ya}$ & 1 \\
\hline \multirow{3}{*}{$\begin{array}{c}\text { Keram } \\
\left(X_{25}\right)\end{array}$} & Tidak & 0 \\
\hline & Kaki / tangan & 0,5 \\
\hline & Kaki \& tangan & 1 \\
\hline \multirow{4}{*}{$\begin{array}{l}\mathrm{BAB} \\
\left(X_{26}\right)\end{array}$} & Normal & 0 \\
\hline & Encer (jarang) & 0,25 \\
\hline & Encer (sering) & 0,5 \\
\hline & Encer berdarah & 1 \\
\hline \multirow{2}{*}{$\begin{array}{c}\text { Ukus diabetes } \\
\text { mellitus } \\
\left(X_{27}\right)\end{array}$} & Tidak & 0 \\
\hline & $\mathrm{Ya}$ & 1 \\
\hline Gatal & Tidak & 0 \\
\hline
\end{tabular}




\begin{tabular}{|c|c|c|}
\cline { 2 - 3 } & Terasa panas & 1 \\
\hline \multirow{2}{*}{$\begin{array}{c}\text { Pandangan } \\
\text { kabur } \\
\left(X_{29}\right)\end{array}$} & Tidak & 0 \\
\cline { 2 - 3 } & Ya & 1 \\
\hline $\begin{array}{c}\text { Tachypnoea } \\
\left(X_{30}\right)\end{array}$ & Tidak & 0 \\
\cline { 2 - 3 } Tachydarcia & Ya & 1 \\
\cline { 2 - 3 }$\left(X_{31}\right)$ & Tidak & 0 \\
\hline $\begin{array}{c}\text { Penurunan } \\
\text { Kesadaran } \\
\left(X_{32}\right)\end{array}$ & Ya & 1 \\
\cline { 2 - 3 } $\begin{array}{c}\text { Bicara tak } \\
\text { beraturan } \\
\left(X_{33}\right)\end{array}$ & Tidak & 0 \\
\hline Tampak & Tidak & 1 \\
\hline $\begin{array}{c}\text { Kuning } \\
\left(X_{34}\right)\end{array}$ & Ya & 1 \\
\hline \multirow{2}{*}{$\begin{array}{c}\text { BAK } \\
\left(X_{35}\right)\end{array}$} & Tidak & 0 \\
\cline { 2 - 3 } & Ya & 1 \\
\cline { 2 - 3 } & Terus menerus & 0.75 \\
\hline
\end{tabular}

\begin{tabular}{|c|c|c|}
\cline { 2 - 3 }$\left(X_{28}\right)$ & Ya & 1 \\
\hline \multirow{4}{*}{$\begin{array}{c}\text { Urine } \\
\left(X_{36}\right)\end{array}$} & Normal & 0 \\
\cline { 2 - 3 } & $\begin{array}{c}\text { Berwarna (selain } \\
\text { warna urine normal })\end{array}$ & 0.2 \\
\cline { 2 - 3 } & Berbusa & 0.4 \\
\cline { 2 - 3 } & Keruh & 0.6 \\
\cline { 2 - 3 } & Berpasir / batu & 0.8 \\
\hline \multirow{2}{*}{$\begin{array}{c}\text { BAK nyeri } \\
\left(X_{37}\right)\end{array}$} & Berdarah & 1 \\
\cline { 2 - 3 } & Tidak & 0 \\
\hline \multirow{2}{*}{$\begin{array}{c}\text { Limfadenopati } \\
\left(X_{38}\right)\end{array}$} & Ya & 1 \\
\cline { 2 - 3 } & Tidak & 0 \\
\hline \multirow{2}{*}{$\begin{array}{c}\text { Bengkak } \\
\left(X_{39}\right)\end{array}$} & Ya & 1 \\
\hline $\begin{array}{c}\text { Edema } \\
\text { tungkai } \\
\left(X_{40}\right)\end{array}$ & Tidak & 0 \\
\cline { 2 - 3 } & Yidak & 1 \\
\cline { 2 - 3 } & Ya & \\
\hline
\end{tabular}

\subsection{Hasil Penelitian Menggunakan Metode Backpropagation}

Pada metode Backpropagation, arsitektur sebuah jaringan akan menentukan keberhasilan target yang akan dicapai karena tidak semua permasalahan dapat diselesaikan dengan arsitektur yang sama. Banyaknya lapisan tersembunyi ditentukan sendiri oleh pengguna sistem melalui cara percobaan konvergensi terbaik (trial dan error) sampai diperoleh hasil konvergensi pelatihan yang paling baik (jumlah epoch terkecil). Parameter sistem masukan untuk pembentukan pola yang dibentuk, yaitu :

\section{Net Size: $\quad$ Input Layer : 40 neuron}

Hidden Layer : 30 neuron 20 neuron 10 neuron 5 neuron dan 1 neuron

Output Layer : 1 neuron

Maksimum epoch / iterasi : 10000

Show Epoch : 100

Dari 190 data pelatihan dan 76 data uji, diperoleh analisis sebagai berikut. Untuk masingmasing variasi nilai $\alpha$, jumlah iterasi maksimum sama yaitu jumlah iterasi (epoch) 10000 . Berikut disajikan dalam tabel hasil dari analisis yang dilakukan:

Tabel 2. Hasil analisa data metode backpropagation

\begin{tabular}{|c|c|c|c|c|c|c|}
\hline \multirow[b]{2}{*}{ No. } & \multirow[b]{2}{*}{ Alpha } & \multirow[b]{2}{*}{ MSE } & \multicolumn{2}{|c|}{ Hasil training } & \multicolumn{2}{|c|}{ Hasil testing } \\
\hline & & & $\begin{array}{l}\text { Data training } \\
\text { yang dikenali }\end{array}$ & $\begin{array}{c}\text { Tingkat } \\
\text { keakuratan }\end{array}$ & $\begin{array}{c}\text { Data testing } \\
\text { yang dikenali }\end{array}$ & $\begin{array}{c}\text { Tingkat } \\
\text { keakuratan }\end{array}$ \\
\hline 1. & 0.2 & 0.0101 & 174 & $91.58 \%$ & 36 & $47.37 \%$ \\
\hline 2. & 0.3 & 0.0100 & 174 & $91.58 \%$ & 39 & $51.32 \%$ \\
\hline 3. & 0.6 & 0.0100 & 174 & $91.58 \%$ & 35 & $46.05 \%$ \\
\hline 4. & 0.7 & 0.0100 & 174 & $91.58 \%$ & 35 & $46.05 \%$ \\
\hline 5. & 0.8 & 0.0100 & 174 & $91.58 \%$ & 42 & $55.26 \%$ \\
\hline 6. & 0.81 & 0.0100 & 174 & $91.58 \%$ & 47 & $61.84 \%$ \\
\hline 7. & 0.82 & 0.0100 & 174 & $91.58 \%$ & 43 & $56.58 \%$ \\
\hline 8. & 0.83 & 0.0100 & 174 & $91.58 \%$ & 43 & $56.58 \%$ \\
\hline 9. & 0.85 & 0.0100 & 174 & $91.58 \%$ & 40 & $52.63 \%$ \\
\hline
\end{tabular}


Berdasarkan tabel di atas, hasil terbaik pada proses training dan testing adalah pada saat $\alpha$ (learningrate) 0.81, dengan maksimum iterasi 5225, nilai MSE 0.0100 (minimum) dan tingkat keakuratan data $91.58 \%$ untuk tahap training dan untuk tahap testing $61.84 \%$.

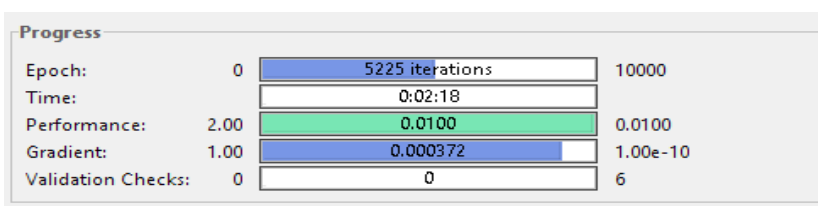

Gambar 5.Progress neural network training

Pada gambar di bawah ini, akan ditunjukkan hasil analisa data dari learning rate 0.5. Hasil perbandingan antara target (o) dan output jaringan (+) dapat diamati dengan cara memperhatikan penempatan posisi output jaringan (+). Jika output jaringan (+) menempati posisi yang sama dengan target (o) maka hasil analisa data tersebut dikatakan benar.

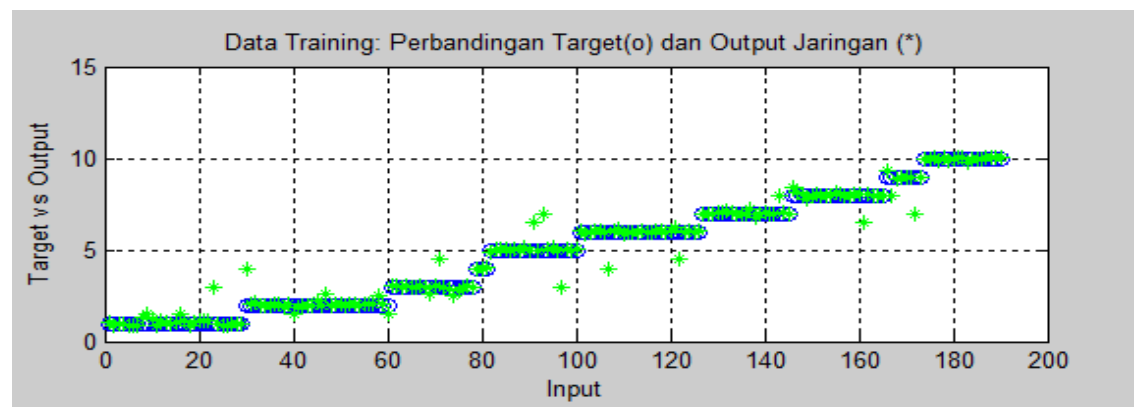

Gambar 6. Grafik hasil training

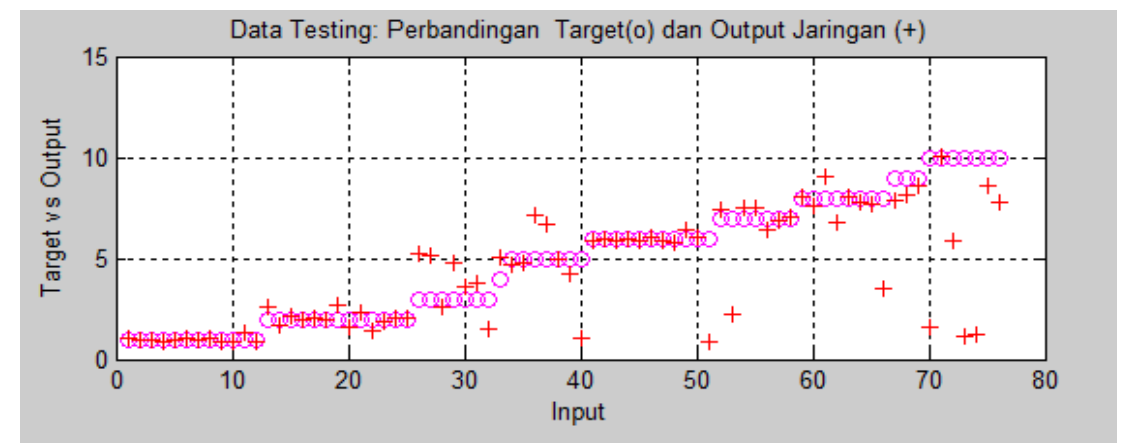

Gambar 7. Grafik hasil testing metode Backpropagation

\subsection{Hasil Penelitian Menggunakan Metode LVQ}

Pada metode Learning Vector Quantization, bobot awal menggunakan data yang diambil secara acak dari data pasien yang ada. Kemudian bobot tersebut akan diubah (di-update) tergantung dari kelas vektor masukan sesuai dengan kelas yang dinyatakan sebagai neuron pemenang. Bobot awal diambil dari data yang sudah ada yang harus dibawa ke dalam bentuk vektor. Pada penelitian ini, data terbagi dalam 10 kelas dengan 40 variabel. Nilai $\alpha$ (learning rate) adalah laju pembelajaran, semakin besar $\alpha$ maka semakin besar langkah pembelajaran. Decrement $\alpha$ besaran nilai yang akan digunakan untuk mengurangi nilai $\alpha$ agar mendekati bobot ideal.

Setelah bobot awal ditentukan, proses training dan testing kemudian dilakukan dengan menggunakan pemrograman MATLAB dengan beberapa nilai $\alpha$ (learning rate) dan Dec $\alpha$ (penurunan learning rate) pada max epoch 10 iterasi, untuk mengetahui tingkat keakuratan terbaik dari metode LVQ. Berdasarkan Tabel 3 dapat disimpulkan bahwa tingkat keakuratan terbaik metode LVQ adalah $93.42 \%$ pada nilai $\alpha$ (learning rate) 0.05 dan Dec $\alpha$ (penurunan learning rate) 0.8 . 
Tabel 3. Hasil testing metode LVQ

\begin{tabular}{|c|c|c|c|c|c|}
\hline \multirow[b]{2}{*}{ No. } & \multirow[b]{2}{*}{ Alpha } & \multirow[b]{2}{*}{$\operatorname{Dec} \alpha$} & \multicolumn{3}{|c|}{ Hasil } \\
\hline & & & $\begin{array}{c}\text { Data uji yang } \\
\text { dikenali }\end{array}$ & $\begin{array}{l}\text { Data uji yang } \\
\text { tidak dikenali }\end{array}$ & $\begin{array}{c}\text { Tingkat } \\
\text { keakuratan }\end{array}$ \\
\hline \multirow{4}{*}{1.} & \multirow{4}{*}{0.1} & 0.2 & 64 & 12 & $84.2 \%$ \\
\hline & & 0.5 & 69 & 7 & $82.9 \%$ \\
\hline & & 0.6 & 70 & 6 & $92.1 \%$ \\
\hline & & 0.7 & 68 & 8 & $89.47 \%$ \\
\hline \multirow{3}{*}{2.} & \multirow{3}{*}{0.5} & 0.2 & 47 & 29 & $61.84 \%$ \\
\hline & & 0.25 & 53 & 23 & $69.74 \%$ \\
\hline & & 0.5 & 51 & 25 & $67.10 \%$ \\
\hline \multirow{3}{*}{3.} & \multirow{3}{*}{0.2} & 0.2 & 62 & 14 & $81.58 \%$ \\
\hline & & 0.5 & 63 & 13 & $82.89 \%$ \\
\hline & & 0.75 & 62 & 14 & $81.58 \%$ \\
\hline \multirow{6}{*}{4.} & \multirow{6}{*}{0.05} & 0.2 & 56 & 20 & $73.68 \%$ \\
\hline & & 0.4 & 62 & 14 & $81.58 \%$ \\
\hline & & 0.6 & 67 & 9 & $88.16 \%$ \\
\hline & & 0.7 & 69 & 7 & $90.79 \%$ \\
\hline & & 0.8 & 71 & 5 & $93.42 \%$ \\
\hline & & 0.85 & 70 & 6 & $92.10 \%$ \\
\hline
\end{tabular}

\section{Simpulan}

Berdasarkan penelitian maka dapat disimpulkan bahwa metode Learning Vector Quantization pada Jaringan Saraf Tiruan lebih baik dalam mendiagnosa penyakit dalam dengan tingkat keakuratan $93.42 \%$, dibandingkan dengan metode Backpropagation yang memiliki tingkat keakuratan diagnosa $61.48 \%$.

\section{Daftar Pustaka}

1. Chou, H. C., Cheng, C. H., and Chang, J. R., 2007, Extracting drug utilization knowledge using self-organizing map and rough set theory, Expert Systems with Applications, 33(2), 499-508.

2. Fausett, L., 1994, Fundamentals Of Neural Network: Architectures, Fundamentals, and Aplications, Prentice-Hall, Inc., New Jersey.

3. Gil, D., Johnsson, M., Chamizo, J. M. G., Soriano, P. A., and Ruiz, F. D., 2009, Application of artificial neural networks in the diagnosis of urological dysfunctions, Expert Systems with Applications, 36(3), 5754-5760.

4. Hagan, M. T., Demuth, H. B., and Beale, M., 1996, Neural Network Design, An International Thompson Pub. Co., USA.

5. Leleury, Z. A., Aulele, S. N., 2016, Perancangan Sistem Diagnosa Penyakit Saluran Pernapasan Menggunakan Metode Learning Vector Quantization (LVQ), Jurnal Matematika Integratif Volume, 12 No 1, April 2016, 1-10.

6. Tanjung, D. H., 2014, Jaringan Saraf Tiruan dengan Backpropagation untuk Memprediksi Penyakit Asma, STMIK Potensi Utama Medan, ISSN: 2354-5771.

7. Temurtas, F., 2007, A comparative study on thyroid disease diagnosis using neural networks, Expert Systems with Applications, 36(1), 944-949. 
Zeth Arthur Leleuryet al / JMI Vol. 12 No. 2, Oktober 2016 pp.89-98 